\title{
Effects of the Irrigation with Treated Wastewaters on the Proximate Composition, Mineral, and Polyphenolic Profile of the Globe Artichoke Heads [Cynara cardunculus (L.)]
}

\author{
Anna Gagliardi, Marcella Michela Giuliani *, Federica Carucci, Matteo Francavilla and \\ Giuseppe Gatta *D \\ Department of Agricultural Food and Environmental Science, University of Foggia, 71121 Foggia, Italy; \\ anna.gagliardi@unifg.it (A.G.); federica.carucci@unifg.it (F.C.); matteo.francavilla@unifg.it (M.F.) \\ * Correspondence: marcella.giuliani@unifg.it (M.M.G.); giuseppe.gatta@unifg.it (G.G.); \\ Tel.: +39-0881-58238 (G.G.)
}

Received: 3 December 2019; Accepted: 27 December 2019; Published: 30 December 2019

\begin{abstract}
The present work was carried out to evaluate the effects of irrigation with two different municipal wastewaters (secondary-treated wastewater (SW) and tertiary-treated wastewater (TW)) compared to freshwater (FW) on main qualitative parameters of three different classes of globe artichoke (main, secondary, and processing heads). The experimental trial was conducted in Southern Italy (Apulia region) for two cropping cycles (GS1 and GS2) using 'Violetto di Provenza' as cultivar. The artichoke heads were analyzed for proximate composition (dry matter, total sugar, total fat, ash, and total protein), percentage of edible part, mineral profile (sodium, potassium, magnesium, calcium, copper, iron, nickel, zinc, chloride, nitrate, phosphate, and sulphate) and polyphenolic acids content (caffeoylquinic acids and flavones). Both SW and TW treatments caused an increase of the percentage of the edible part, head protein contents, and mineral elements of the main and processing heads. Moreover, SW statistically increased the caffeoylquinic acid derivatives and the trans-ferulic acid content, while both SW and TW the flavones content. Finally, according to the multivariate analysis adopted, in our experimental conditions, the mineral component of the heads, such as chloride, potassium, copper, and zinc content, had a greater weight in the separation of FW, SW, and TW. On the other hand, the polyphenolic 5-O-caffeoylquinic acid, trans-ferulic acid, and 1,5-di-O-caffeoylquinic acid had a greater weight in the separation of the head class groups (main, secondary, and processing). Moreover, the trans-ferulic acid content of the heads was related both to the irrigation water type and to the different head classes.
\end{abstract}

Keywords: reclaimed wastewater; globe artichoke; crop quality; polyphenolic compounds; food analysis; antioxidant activity

\section{Introduction}

Worldwide water availability is decreasing, especially in semi-arid Mediterranean areas in which, due to climate change, the frequency and severity of prolonged periods of drought as well as strong seasonal variation in the water budget are predicted [1]. The reduced availability of water resource is the main reason for the increasing trend in wastewater reuse in agriculture worldwide [2,3]. This practice could ensure the transfer of nutrients, such as nitrogen, phosphorus, macro, and micro-minerals into agricultural soil, that represent a good source of nutrients needful for plant growth, yield, and quality $[4,5]$. In particular, micro minerals are beneficial for the plant growth and metabolism at lower concentrations, but become toxic when exceed the requirement $[3,6,7]$. Their accumulation in plant 
tissues can affect different parameters of metabolism such as photosynthesis, mineral distribution, and antioxidant protection systems [8] resulting in growth inhibition, decrease in biomass, with unfavorable effects on productivity and quality of crops $[9,10]$. Furthermore, micro minerals are known to induce generation of reacting oxygen species (ROS) and free radicals, which can cause peroxidation of lipid membrane leading to increased permeability and oxidative stress to the plants [11]. Several researches were carried out on herbaceous crops in Mediterranean environment in order to evaluate the effects of treated wastewater reuse for irrigation on physical, chemical, and microbiological soil properties and on edible plant products. In a multi-year study, carried out on vegetable crops rotation (processing tomato, fennel, and lettuce) with two types of water (conventional and treated wastewater), no significant differences in crop production and accumulation of micro minerals in soil and in plants were detected [12].

Globe artichoke is an ancient, high-N-demanding herbaceous perennial crop, originating from the Mediterranean area [3,13], which represents an important resource for the Southern Europe agricultural economy. Nowadays, thanks also to its reputation as a functional food [14], it is widely cultivated all over the world $[15,16]$. The annual world production of edible artichoke is approximately $1452 \mathrm{kt}$ ( 124.900, 0 cultivated hectares) and it is located specifically in Southern Europe (i.e., Italy, Spain, France, Greece), the Middle East (i.e., Turkey, Syria, Israel), northern Africa (i.e., Egypt, Morocco, Algeria, Tunisia), and in the last few years, China and USA as well [13,17]. Italy, where the crop is mainly present in irrigated farmland of southern regions, is one of the leading artichoke producers worldwide [16]. Here, the edible parts (immature inflorescence also referred to as capitula or heads) are harvested during both autumn-winter (early production for fresh market) and spring (late production for industrial processes) [18]. Globe artichoke plays a significant role in human nutrition; it provides a dietary source of vitamin C, several minerals (potassium, sodium, phosphorus, and iron), low amount of lipids, dietary fiber, and high level of nutraceutical compounds [15]. The antioxidant and health protective properties of artichoke have been consistently related to its high levels of phenolic acids and flavonoids present in fresh edible part [19-22]. The main phenolic compounds in artichoke heads are caffeoylquinic acid derivatives, particularly chlorogenic acid (5-O-caffeoylquinic acid), 1,5-di-O-caffeoylquinic acid, and 3,5-di-O-caffeoylquinic acid [14,15,20,23], and flavones such as apigenin and luteolin (both glycosides and rutinosides) [15,24]. These polyphenolic compounds have a marked scavenging activity against ROS and free radicals, acting as a protective pool against oxidative damage to biological molecules, such as protein and lipids [25].

The quantitative and qualitative variability of essential nutrient and secondary metabolites in artichoke heads depends on genetic diversity, physiological stage of development (harvest time), and climatic conditions during plant growth $[19,24,26]$. Moreover, the irrigation management, including the water quality parameters, may also influence the availability of both essential nutrient and secondary metabolites. In the literature, there are some studies regarding the effect of the use of treated wastewaters on the yield, quality, and microbiological properties of the main horticultural crops [27,28]; however, to the best of our knowledge, no information are available on the quality aspects, in particular, polyphenolic profile, of the artichoke grown in Mediterranean area under wastewater irrigation.

The aim of this work was to evaluate the effects of drip irrigation with two different municipal wastewaters (secondary-treated wastewater, SW) and tertiary-treated wastewater, TW) compared to freshwater (FW) on proximate composition, mineral, and polyphenolic profile of different classes of globe artichoke (main, secondary, and processing heads) grown under Mediterranean climate conditions.

\section{Materials and Methods}

\subsection{Site Description and Field Experimental Setup}

The experimental trial was conducted in Southern Italy, Apulia region (Trinitapoli, $41^{\circ} 21^{\prime} \mathrm{N}$, $16^{\circ} 03^{\prime} \mathrm{E}$; altitude $10 \mathrm{~m}$ a.s.l.) during two cropping cycles (2012-2013 and 2013-2014) on globe artichoke [Cynara cardunculus (L.), subsp. scólymus Hayek], cultivar 'Violetto di Provenza'. 
The area is characterized by typical Mediterranean climate, with air temperatures that drops below $0{ }^{\circ} \mathrm{C}$ in winter and exceed peaks of $40^{\circ} \mathrm{C}$ in summer. The long-term average annual rainfall is of $590 \mathrm{~mm}$, with precipitations unevenly distributed throughout the year and mainly concentrated in the period from October to April. During the experimental period, the daily meteorological parameters, such as maximum and minimum air temperature, maximum and minimum air relative humidity, and total precipitation, were recorded by a weather station near to the experimental area [29] (Table S1).

The experimental trial was performed in a loam soil (United States Department of Agriculture classification) with the following main chemical properties: Organic matter, $1.2 \%$; available phosphorus, $114.0 \mathrm{mg} \mathrm{kg}^{-1}$; total potassium, $1.27 \mathrm{~g} \mathrm{~kg}^{-1}$; total nitrogen, $0.91 \%$.

Three types of irrigation water were applied to the crop: freshwater (FW), secondary municipal wastewater (SW), and tertiary municipal wastewater (TW). The FW was obtained from the irrigation network system that is usually used by the farmers in the area for crop irrigation (Marana Capacciotti dam); the SW and TW were from secondary and tertiary municipal water recycling plants near the experimental site. The wastewater was treated in the wastewater treatment plant based on the following processes: (i) Primary treatments, such as screening, oil removal, equalization, and $\mathrm{pH}$ adjustment; (ii) secondary treatments, such as activated sludge process (anoxic plus aerobic phases) and chemically assisted secondary sedimentation; (iii) tertiary treatments, such as chlorination, sand filtration, and membrane ultrafiltration.

The experimental field was arranged according to a complete randomized block design with the irrigation treatments (FW, SW, and TW) replicated three times for a total of 9 plots (3 irrigation treatments $\times 3$ replicates). Each plot was $16.8 \mathrm{~m} \times 6.0 \mathrm{~m}$. In the first growing season (GS1), the artichoke plants were transplanted as offshoots on 15 July 2012 in rows $1.20 \mathrm{~m}$ apart and with $1.20 \mathrm{~m}$ spacing within the rows to provide a density of 6944 plants ha $^{-1}$. In the second growing season (GS2), the plants were re-awakened on 20 July 2013 and irrigated until the soil field capacity was reached. A drip irrigation system was used with dripper lines placed along each plant row. The in-line drippers were located $0.40 \mathrm{~m}$ apart; the dripper flow rate was $4 \mathrm{~L} \mathrm{~h}^{-1}$ at an operating pressure of $0.15 \mathrm{MPa}$. Irrigation was performed whenever the water lost by crop evapotranspiration (ETc) reached a predetermined level ( $30 \mathrm{~mm}$, i.e., $~ 50 \%$ of available water depletion) in the soil layer containing the roots. The watering volume used restored 100\% of the water lost. During the GS1 and GS2 growing cycles, the seasonal water irrigation volumes applied were $3300 \mathrm{~m}^{3} \mathrm{ha}^{-1}$ and $3000 \mathrm{~m}^{3} \mathrm{ha}^{-1}$, respectively. All agricultural management practices, including weed and pest control, applied to artichoke crop during the two growing seasons, were performed according to the agronomic techniques commonly adopted by local farmers.

\subsection{Water and Plant Sampling}

Water samples were collected and analyzed seven times during GS1 and GS2, respectively. At each sampling date, three samples of each water type were collected using $1000 \mathrm{~mL}$ sterile glass bottles, transported to the laboratory in refrigerated bags, and stored in a refrigerator at $4{ }^{\circ} \mathrm{C}$. To prevent microbial activity, $1 \mathrm{~mL}$ concentrated $\mathrm{HNO}_{3}$ was added to each water sample; the samples were examined within $24 \mathrm{~h}$ from the collection. The water analyses were performed as reported in Gatta et al. (2016) [3]. The nutrients content of the irrigation waters is reported in Table 1.

Samples of artichoke heads (edible plant) were collected at three times (November, March, and May) during each growing season, by picking five marketable artichoke heads from each experimental plot (for a total of 270 artichoke heads in the two growing seasons). The artichoke head samples were placed in clean plastic bags, labelled, and transported to the laboratory. The picked heads were classified as: (i) Main heads including the early yield from October until December; (ii) secondary heads including the mid-yield from January until April; and (iii) processing heads including the late yield (May). 
Table 1. Supply of mineral nutrients to the soil through the fertigation and the different irrigation water treatments.

\begin{tabular}{|c|c|c|c|c|c|c|c|c|c|c|c|}
\hline \multirow[t]{2}{*}{$\begin{array}{c}\text { Yield } \\
\text { (Head Class) }\end{array}$} & \multirow[t]{2}{*}{$\begin{array}{l}\text { Irrigation } \\
\text { Treatment }\end{array}$} & \multirow[t]{2}{*}{$\begin{array}{c}\text { Volume Applied } \\
\left(\mathrm{m}^{3} \mathrm{ha}^{-1}\right)\end{array}$} & \multicolumn{2}{|c|}{$\begin{array}{l}\text { Supplied with Irrigation } \\
\text { Water }\left(\mathrm{kg} \mathrm{ha}^{-1}\right)\end{array}$} & \multicolumn{3}{|c|}{$\begin{array}{c}\text { Supplied with Fertigation } \\
\left(\mathrm{kg} \mathrm{ha}^{-1}\right)\end{array}$} & \multicolumn{4}{|c|}{$\begin{array}{l}\text { Total Amount Supplied } \\
\qquad\left(\mathrm{kg} \mathrm{ha}^{-1}\right)\end{array}$} \\
\hline & & & Nitrogen & Phosphorus & Potassium & Nitrogen & Phosphorus & Potassium & Nitrogen & Phosphorus & Potassium \\
\hline \multirow{2}{*}{$\begin{array}{l}\text { Early yield } \\
\text { (Main) }\end{array}$} & FW & 1850 & 2.01 & 0.28 & 14.99 & 180 & 70 & 80 & 182.01 & 70.28 & 94.99 \\
\hline & TW & 1850 & 38.94 & 11.29 & 48.84 & 180 & 70 & 80 & 218.94 & 81.29 & 128.84 \\
\hline \multirow{3}{*}{$\begin{array}{l}\text { Mid-yield } \\
\text { (Secondary) }\end{array}$} & FW & 350 & 0.38 & 0.05 & 2.48 & \multirow{3}{*}{-} & \multirow{3}{*}{-} & \multirow{3}{*}{-} & 0.38 & 0.05 & 2.48 \\
\hline & SW & 350 & 10.55 & 1.94 & 9.22 & & & & 10.55 & 1.94 & 9.22 \\
\hline & TW & 350 & 7.37 & 2.14 & 9.24 & & & & 7.37 & 2.14 & 9.24 \\
\hline \multirow{2}{*}{$\begin{array}{l}\text { Late yield } \\
\text { (Processing) }\end{array}$} & SW & 950 & 28.64 & 5.27 & 25.03 & \multirow[t]{2}{*}{-} & \multirow[t]{2}{*}{-} & \multirow[t]{2}{*}{-} & 28.64 & 5.27 & 25.03 \\
\hline & TW & 950 & 20.00 & 5.80 & 25.08 & & & & 20.00 & 5.80 & 25.08 \\
\hline \multirow[t]{3}{*}{ Total } & FW & 3150 & 3.42 & 0.47 & 25.17 & 180 & 70 & 80 & 183.42 & 70.47 & 105.17 \\
\hline & SW & 3150 & 94.97 & 17.48 & 83.00 & 180 & 70 & 80 & 274.97 & 87.48 & 163.00 \\
\hline & TW & 3150 & 66.31 & 19.22 & 83.16 & 180 & 70 & 80 & 246.31 & 89.23 & 163.16 \\
\hline
\end{tabular}




\subsection{Qualitative Parameters Analysis of Artichoke Heads}

\subsubsection{Proximate Composition and Mineral Profile Analysis}

The weight of each harvested head was determined and, after the complete removal of the floral stem, the heads were reweighted to obtain the edible part (\% edible part on fresh weight).

Moisture content was determined by drying artichoke heads at $65^{\circ} \mathrm{C}$ until constant weight was reached. The ash content was calculated through incineration at $550{ }^{\circ} \mathrm{C}$ in a muffle for $6 \mathrm{~h} \mathrm{[30].}$

Total nitrogen was determined using the Kjeldahl method. Crude protein content was then calculated by multiplying total nitrogen by the coefficient 6.25 . Total fat content was measured after an extraction procedure on the sample with a Soxhlet device [30]. Total soluble sugars were extracted from $10 \mathrm{~g}$ of dry raw material with $100 \mathrm{~mL}$ of distilled water [31] and quantified according to Fehling method [32].

The sodium, potassium, magnesium, calcium, chloride, nitrate, phosphate, and sulphate content was determined by ion-exchange chromatography (Dionex ICS-1100, Dionex Corporation, Sunnyvale, CA, USA). Anions were extracted from samples (0.5 g d.w.) with $50 \mathrm{~mL} 3.5 \mathrm{mmol}{ }^{-1} \mathrm{Na}_{2} \mathrm{CO}_{3}$ and $1.0 \mathrm{mmol}^{-1} \mathrm{NaHCO}_{3}$, and they were separated and quantified using Dionex equipped with an IonPac AG14 precolumn and an IonPac AS14 column. Cations, were analyzed after incineration of samples (1.0 g d.w.) at $550{ }^{\circ} \mathrm{C}$ and acid digestion in $20 \mathrm{~mL}$ of $1.0 \mathrm{~mol} \mathrm{l}^{-1} \mathrm{HCl}$ at $99.5 \pm 0.5{ }^{\circ} \mathrm{C}$, for $30 \mathrm{~min}$. The resulting solution was filtered, diluted, and quantified using Dionex equipped with an IonPac CG12A guard column and an IonPac CS12A analytical column. The data were expressed as mg kg-1 dry weight (d.w.) [33].

Copper, iron, nickel, and zinc content was analyzed with an induced coupled plasma optical emission spectrometer (ICP-OES). Before analytical process, samples ( $0.5 \mathrm{~g} \mathrm{~d}$.w.) were dissolved in $10 \mathrm{~mL} \mathrm{HNO} 3 / \mathrm{H}_{2} \mathrm{O}_{2}(3: 1 \mathrm{v} / \mathrm{v})$ by microwave assisted mineralization (CEM-Mars6). Digested samples were then diluted with Milli-Q water to $50 \mathrm{~mL}$ (US-EPA 1989, method 3050 B) [34] and analyzed by ICP-OES. The data were expressed as $\mathrm{mg} \mathrm{kg}^{-1}$ dry weight (d.w.).

\subsubsection{HPLC Analysis of Polyphenolic Profile}

Dried head samples $(1.5 \mathrm{~g})$ were extracted with $6 \mathrm{~mL}$ of methanol/water $(80: 20, v / v)$ by high-speed homogenization at 11,000 rpm (Ultra-Turrax T18) and then stirred at room temperature for $1 \mathrm{~h}$. The mixture was centrifuged for $20 \mathrm{~min}$ at $18,500 \mathrm{rpm}$ and $4{ }^{\circ} \mathrm{C}$ (Beckman Coulter Allegra 25, Fullerton, CA, USA), filtered through $0.20 \mu \mathrm{m}$ nylon syringe filters and stored at $-20{ }^{\circ} \mathrm{C}$ until HPLC analysis was performed. Each sample was extracted in triplicate.

Liquid chromatographic analysis was performed with a HPLC system 1260 Infinity (Agilent Technologies) equipped with a degasser G4225A, a binary pump (0-60 MPa) G1312B, an auto sampler G1329B, a column oven (20-80 $\left.{ }^{\circ} \mathrm{C}\right) \mathrm{G1316A}$, and Diode Array Detector G1315C. The chromatographic separation was performed using a reversed phase Zorbax Stable Bond SB-C18 column $(250 \times 4.6 \mathrm{~mm}$ i.d., particle size $5 \mu \mathrm{m}$, Agilent Technologies) with a Zorbax precolumn guard cartridge $10 \mathrm{~mm} \times 4 \mathrm{~mm}$ i.d. $5 \mu \mathrm{m}$. The injection volume was set at $20 \mu \mathrm{L}$ and the column temperature was kept at $25{ }^{\circ} \mathrm{C}$.

The eluents were (A) $0.1 \%$ formic acid in water and (B) $0.1 \%$ formic acid in acetonitrile/methanol $(60: 40 \mathrm{v} / \mathrm{v})$. All solvents were HPLC grade. The gradient program was as follows: $20-30 \% \mathrm{~B}(6 \mathrm{~min})$, $30-40 \%$ B (10 min), 40-50\% B (8 min), 50-90\% B (8 min), 90-90\% B (3 min), 90-20\% B (3 min), at a constant flow of $0.8 \mathrm{~mL} \mathrm{~min}^{-1}$. Diode array detection was set between 200 and $600 \mathrm{~nm}$, and absorbance was recorded at 280,330, and $350 \mathrm{~nm}$.

Standards with high purities were purchased from Sigma-Aldrich including chlorogenic acid ( $\geq 96 \%$ purity), caffeic acid ( $\geq 97 \%$ purity), 1,3-di-caffeoylquinic acid ( $\geq 95 \%$ purity), ferulic acid ( $\geq 95 \%$ purity), 1,5-di-caffeoylquinic acid ( $\geq 95 \%$ purity), 1-caffeoylquinic acid (97\% purity), apigenin (95\% purity), and luteolin ( $\geq 95 \%$ purity). The stock solutions were prepared with the concentration of $1000 \mathrm{mg} / \mathrm{L}$ by HPLC grade methanol. 
Caffeoylquinic acids and flavones were identified by their retention times, comparison with commercially available standards, their UV/Vis spectra and available data in the literature $[20,24,35,36]$. The followed compounds were identified: caffeic acid (CafA); 5-O-caffeoylquinic acid (chlorogenic acid; 5-CQA.); 1,3 di-O-caffeoylquinic acid (cynarin; 1,3-diCQA); 1,5-di-O-caffeoylquinic acid (1,5-diCQA); 3,4-di-O-caffeoylquinic acid (3,4-diCQA); apigenin 7-O-glucoside (Api-glc); apigenin 7-O-rutinoside (Api-rut); luteolin 7-O-glucoside (Lut-glc); luteolin 7-O-glucuronide (Lut-glr); luteolin 7-O-rutinoside (Lut-rut); 4-hydro-3-methylcinnamale (trans-ferulic acid; TFA).

Amounts of mono- and di-caffeoylquinic acids were calculated at $330 \mathrm{~nm}$ using 5-caffeoylquinic acid as reference. Apigenin derivatives were quantified at $330 \mathrm{~nm}$ using apigenin-7-O-glucoside as reference, while luteolin derivatives were quantified at $350 \mathrm{~nm}$ using luteolin $7-O$-glucoside. All data are reported as $\mathrm{mg} 100 \mathrm{mg}^{-1}$ of dry matter (DM).

\subsection{Statistical Analysis}

The dataset was tested according to the basic assumptions for the analysis of variance (ANOVA). The normal distribution of the experimental error and the common variance of the experimental error were verified through Shapiro-Wilk and Bartlett's tests, respectively. When required, Box-Cox transformations [37] were applied prior to analysis.

A combined statistical analysis was performed for all data among the irrigation treatment and growing season factors. The irrigation treatment was considered as a fixed factor, whereas growing season was considered as a random factor. The differences in the means were determined using Tukey's honest significance difference post-hoc tests at the $5 \%$ probability level. In addition, the qualitative variables were jointly considered in a multivariate approach and statistically processed applying a stepwise discriminant analysis (SDA) with the two experimental factors (irrigation treatment and heads class) as discriminating sources [38,39]. This multivariate technique was used to explain the differences among groups within each factor and to evaluate the main parameter(s) that played the most important role in determining those differences. The qualitative parameters were stepwise introduced as predictor variables into the discriminant analysis. Before performing the SDA, the values of each parameter were correctly standardized. According to the 'stepwise' procedure, the variables were included in the model one by one, choosing at each step the variable that made the most significant additional contribution to the discrimination (i.e., with the largest Fisher's test value, F-ratio). Based on the selected variables, different discriminant functions (canonical axis, CAs) were computed by discriminant analysis.

The first two CAs accounted for the larger portion of the data variability, and they were considered for further data analysis. The selected CAs were represented graphically in a biplot, in which the canonical scores were plotted as symbols, whereas standardized canonical coefficients for each of the original variables were reported as vectors and used for interpretation.

ANOVA and SDA analysis were performed using the JMP software package, version 14.3 (SAS Institute Inc., Cary, NC, USA), and graphs were constructed using the SigmaPlot software (Systat Software, Chicago, IL, USA).

\section{Results}

\subsection{Weather Conditions}

The rainfall distribution was not uniform during both growing seasons, and rainy days were more concentrated in the winter season than in the spring and summer (from October to March), with about $390 \mathrm{~mm}$ for GS1 and about $300 \mathrm{~mm}$ for GS2 (Table S1, Supplementary Materials).

According to the Mediterranean climate, in both GS, maximum and minimum temperatures decreased progressively from November to February and then increased up to May. In particular, the lowest monthly minimum air temperatures $\left(2.0^{\circ} \mathrm{C}\right)$ were recorded in February for both GS, while the highest monthly maximum air temperatures were recorded in July for GS1 $\left(34.6{ }^{\circ} \mathrm{C}\right)$. The thermal 
excursion (as difference between maximum and minimum temperature in a month) was higher in GS1 than in GS2 (more evident in November and February). As expected, solar radiation levels showed the same trend of temperatures in both growing seasons.

\subsection{Proximate Composition and Mineral Profile of the Artichoke Heads}

Statistical analysis showed that GS did not significantly influence the qualitative parameters considered (low values of explained sum of square and Fischer's test not significant), while IT factor significantly $(P \leq 0.05)$ influenced only the protein content and the percentage of the edible part. Moreover, the interaction GS $\times$ IT factors was not significant for all parameters analyzed (Table S2, Supplementary Materials).

Figure 1 shows the effects of water irrigation treatments on the percentage of edible part and protein content of artichoke heads. SW and TW irrigation treatments showed higher edible part compared to FW for both main and processing heads, showing an increase of the $7 \%$ and $16 \%$, respectively (Figure 1A). The protein content of the main and processing heads was also significantly $(P \leq 0.05)$ higher for wastewater treatments compared to FW (Figure 1B). In particular, the use of SW and TW resulted in an increase of $11 \%$ of protein content in main heads compared to FW; highest differences were found in protein content of processing heads with an increase of $27 \%$ in SW-treated samples. No significant effect for the secondary head class was observed.
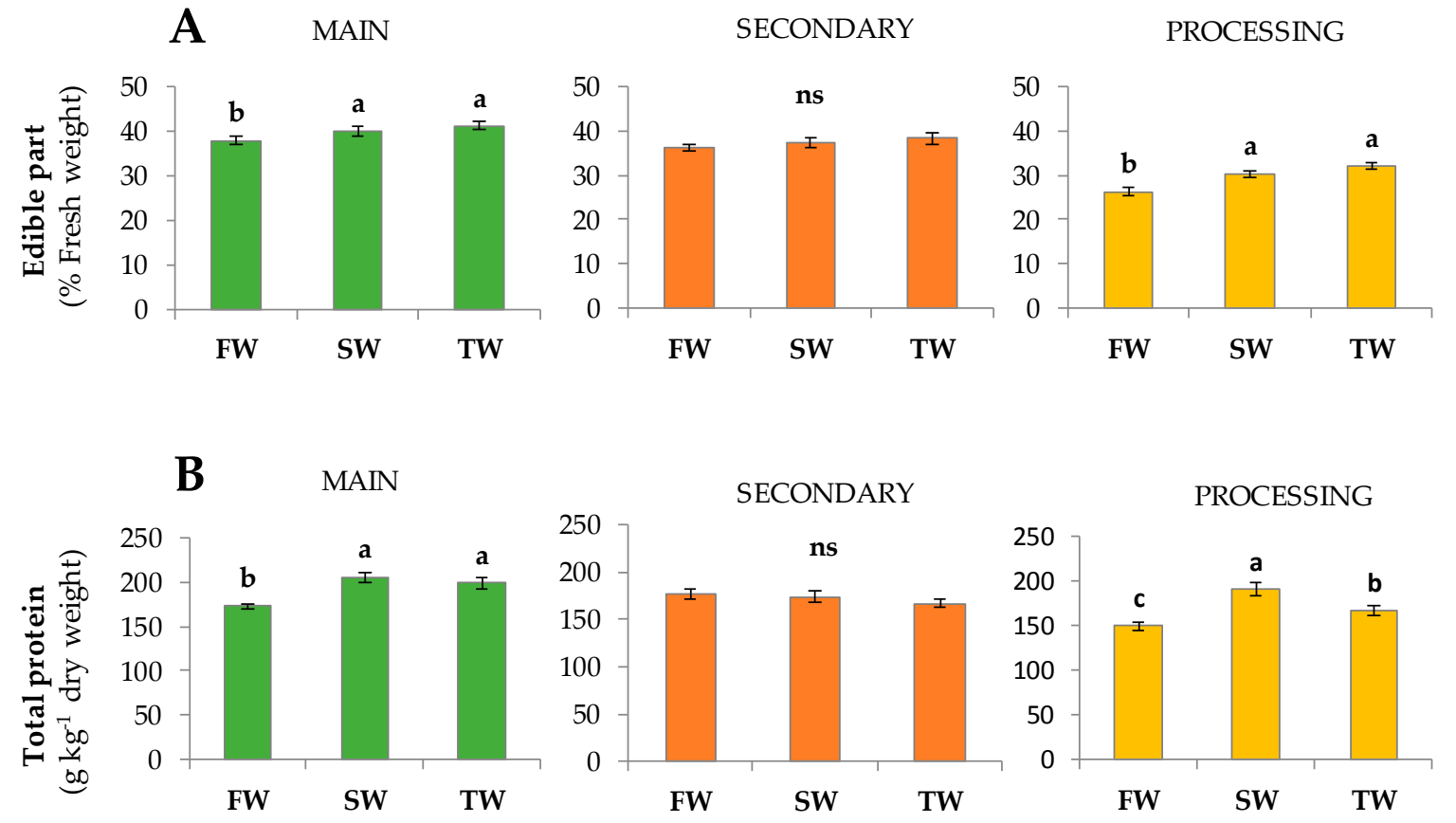

Figure 1. Effects of water irrigation treatments on percentage edible part (A) and protein content (B) of artichoke head. For each fraction (main, secondary, and processing), different superscript letters indicate statistically significant differences $(P \leq 0.05)$ and ns, not significant $(P \geq 0.05)$, according to Tukey's test. Vertical bars indicate standard errors of three replicates. FW, fresh water; SW, secondary wastewater; TW, tertiary wastewater.

Under our experimental conditions, the average values of dry matter, total sugar, total fat, and ash of artichoke heads were not significantly affected by different irrigation water used. Their mean values were $12 \%$ fresh weight basis, $95 \mathrm{~g} \mathrm{~kg}^{-1}$ d.w., $8.1 \mathrm{~g} \mathrm{~kg}^{-1}$ d.w., and $70 \mathrm{~g} \mathrm{~kg}^{-1}$ d.w., for dry matter, total sugars, total fat, and ash, respectively.

The effects, in terms of deviance (sum of square), explained by the growing season (GS) and the irrigation treatments (IT), on the mineral profile of the artichoke heads were investigated (Table S3, 
Supplementary Materials). The IT factor significantly $(P \leq 0.05)$ influenced the mineral elements content, while GS did not (except for potassium content) as well as the interaction GS $\times$ IT.

The mineral elements profile found in artichoke heads cultivated under different irrigation treatment is reported in Table 2. The potassium content in main and processing heads was significantly higher for SW and TW with respect to FW, while no significant differences were observed for the secondary heads among the irrigation treatments. A similar behavior was observed for sodium content. IT factor significantly affected the magnesium content only for main and processing head classes. In particular, the highest value was observed for the processing heads under TW. The calcium head content was not affected by IT factor. Moreover, SW showed values significantly higher than TW for iron, zinc, chloride, and nitrate content in the main heads and for copper, iron, nickel, zinc, and nitrate content in the processing heads. Finally, the irrigation treatment did not influence the sulphate content of the artichoke heads.

Table 2. Effects of water irrigation treatments (IT) on mineral profile of artichoke head.

\begin{tabular}{|c|c|c|c|c|c|c|}
\hline \multirow[t]{2}{*}{$\mathrm{IT}^{\dagger}$} & & \multicolumn{2}{|c|}{ Sodium (g kg ${ }^{-1}$ d.w.) } & \multicolumn{3}{|c|}{ Potassium ( $\mathrm{g} \mathrm{kg}^{-1}$ d.w.) } \\
\hline & Main & Secondary & Processing & Main & Secondary & Processing \\
\hline FW & $2.0 \pm 0.2^{b}$ & $1.6 \pm 0.2^{a}$ & $2.4 \pm 0.2^{b}$ & $13.8 \pm 0.4^{\mathrm{c}}$ & $15.4 \pm 1.6^{\mathrm{a}}$ & $14.5 \pm 0.5^{b}$ \\
\hline SW & $3.3 \pm 0.2^{\mathrm{a}}$ & $2.0 \pm 0.1^{\mathrm{a}}$ & $3.7 \pm 0.2^{\mathrm{a}}$ & $15.2 \pm 0.3^{b}$ & $17.4 \pm 0.6^{\mathrm{a}}$ & $19.7 \pm 1.1^{\mathrm{a}}$ \\
\hline \multirow[t]{3}{*}{ TW } & $3.8 \pm 0.1^{\mathrm{a}}$ & $1.6 \pm 0.2^{\mathrm{a}}$ & $4.0 \pm 0.3^{\mathrm{a}}$ & $18.3 \pm 0.6^{\mathrm{a}}$ & $18.6 \pm 1.0^{\mathrm{a}}$ & $19.1 \pm 1.0^{\mathrm{a}}$ \\
\hline & & \multicolumn{2}{|c|}{ Magnesium (g kg ${ }^{-1}$ d.w.) } & \multicolumn{3}{|c|}{ Calcium (g kg ${ }^{-1}$ d.w.) } \\
\hline & Main & Secondary & Processing & Main & Secondary & Processing \\
\hline FW & $1.4 \pm 0.1^{b}$ & $2.1 \pm 0.2^{a}$ & $2.4 \pm 0.2^{\mathrm{c}}$ & $2.7 \pm 0.1^{a}$ & $2.4 \pm 0.1^{a}$ & $2.4 \pm 0.1^{\mathrm{a}}$ \\
\hline SW & $1.5 \pm 0.1^{a b}$ & $2.4 \pm 0.3^{\mathrm{a}}$ & $2.6 \pm 0.1^{b}$ & $2.7 \pm 0.2^{\mathrm{a}}$ & $2.5 \pm 0.2^{\mathrm{a}}$ & $2.4 \pm 0.2^{\mathrm{a}}$ \\
\hline TW & $1.6 \pm 0.1^{\mathrm{a}}$ & $2.5 \pm 0.2^{\mathrm{a}}$ & $2.7 \pm 0.2^{a}$ & $2.6 \pm 0.2^{a}$ & $2.4 \pm 0.2^{a}$ & $2.4 \pm 0.2^{a}$ \\
\hline \multirow[t]{2}{*}{$\mathrm{IT}^{\dagger}$} & & \multicolumn{2}{|c|}{ Copper (mg kg ${ }^{-1}$ d.w.) } & \multicolumn{3}{|c|}{ Iron (mg kg ${ }^{-1}$ d.w.) } \\
\hline & Main & Secondary & Processing & Main & Secondary & Processing \\
\hline FW & $9.6 \pm 0.5^{b}$ & $9.6 \pm 1.4^{\mathrm{a}}$ & $8.2 \pm 0.6^{c}$ & $49.3 \pm 1.4^{c}$ & $55.0 \pm 4.6^{\mathrm{a}}$ & $45.2 \pm 2.5^{c}$ \\
\hline SW & $14.4 \pm 1.3^{\mathrm{a}}$ & $13.4 \pm 0.6^{\mathrm{a}}$ & $13.4 \pm 1.3^{\mathrm{a}}$ & $77.5 \pm 4.3^{\mathrm{a}}$ & $67.4 \pm 3.4^{\mathrm{a}}$ & $71.1 \pm 3.3^{\mathrm{a}}$ \\
\hline \multirow[t]{3}{*}{ TW } & $13.4 \pm 1.0^{\mathrm{a}}$ & $12.0 \pm 0.8^{a}$ & $11.3 \pm 0.7^{b}$ & $65.8 \pm 2.6^{b}$ & $59.8 \pm 2.0^{\mathrm{a}}$ & $60.8 \pm 2.5^{b}$ \\
\hline & & \multicolumn{2}{|c|}{ Nickel (mg kg ${ }^{-1}$ d.w.) } & \multicolumn{3}{|c|}{ Zinc (mg kg ${ }^{-1}$ d.w.) } \\
\hline & Main & Secondary & Processing & Main & Secondary & Processing \\
\hline FW & $1.5 \pm 0.2^{b}$ & $1.7 \pm 0.1^{\mathrm{a}}$ & $1.1 \pm 0.1^{b}$ & $53.6 \pm 2.0^{c}$ & $50.9 \pm 5.9^{a}$ & $41.9 \pm 4.0^{c}$ \\
\hline SW & $2.3 \pm 0.2^{\mathrm{a}}$ & $2.0 \pm 0.2^{\mathrm{a}}$ & $2.1 \pm 0.2^{\mathrm{a}}$ & $99.5 \pm 4.7^{\mathrm{a}}$ & $67.6 \pm 1.5^{\mathrm{a}}$ & $64.7 \pm 4.4^{\mathrm{a}}$ \\
\hline \multirow[t]{3}{*}{ TW } & $2.1 \pm 0.1 \mathrm{ab}$ & $1.9 \pm 0.2^{\mathrm{a}}$ & $1.4 \pm 0.1^{b}$ & $77.7 \pm 2.1^{b}$ & $60.0 \pm 3.7^{a}$ & $53.4 \pm 2.2^{b}$ \\
\hline & & \multicolumn{2}{|c|}{ Chloride (g kg ${ }^{-1}$ d.w.) } & \multicolumn{3}{|c|}{ Nitrate (g kg ${ }^{-1}$ d.w.) } \\
\hline & Main & Secondary & Processing & Main & Secondary & Processing \\
\hline FW & $5.2 \pm 0.1^{c}$ & $6.3 \pm 0.2^{a}$ & $5.8 \pm 293.2^{b}$ & $0.32 \pm 0.03^{c}$ & $0.38 \pm 0.02^{a}$ & $0.36 \pm 0.02^{b}$ \\
\hline SW & $8.7 \pm 0.4^{\mathrm{a}}$ & $7.2 \pm 0.3^{\mathrm{a}}$ & $7.3 \pm 239.0^{\mathrm{a}}$ & $0.64 \pm 0.05^{\mathrm{a}}$ & $0.43 \pm 0.03^{a}$ & $0.47 \pm 0.03^{a}$ \\
\hline \multirow[t]{3}{*}{ TW } & $6.8 \pm 0.2^{b}$ & $7.1 \pm 0.4^{\mathrm{a}}$ & $7.5 \pm 395.7^{\mathrm{a}}$ & $0.46 \pm 0.02^{b}$ & $0.43 \pm 0.03^{a}$ & $0.38 \pm 0.03^{b}$ \\
\hline & & \multicolumn{2}{|c|}{ Phosphate (g kg ${ }^{-1}$ d.w.) } & \multicolumn{3}{|c|}{ Sulphate (g kg ${ }^{-1}$ d.w.) } \\
\hline & Main & Secondary & Processing & Main & Secondary & Processing \\
\hline FW & $17.6 \pm 1.4^{b}$ & $15.6 \pm 1.0^{\mathrm{a}}$ & $13.4 \pm 0.05^{\mathrm{a}}$ & $4.5 \pm 0.3^{\mathrm{a}}$ & $4.6 \pm 0.2^{\mathrm{a}}$ & $4.5 \pm 0.3^{\mathrm{a}}$ \\
\hline SW & $24.4 \pm 1.2^{\mathrm{a}}$ & $17.2 \pm 1.3^{\mathrm{a}}$ & $13.8 \pm 0.2^{\mathrm{a}}$ & $4.9 \pm 0.2^{\mathrm{a}}$ & $4.9 \pm 0.3^{a}$ & $4.9 \pm 0.4^{\mathrm{a}}$ \\
\hline TW & $25.3 \pm 1.9^{a}$ & $15.8 \pm 0.8^{\mathrm{a}}$ & $14.0 \pm 0.2^{\mathrm{a}}$ & $5.0 \pm 0.4^{\mathrm{a}}$ & $5.1 \pm 0.3^{\mathrm{a}}$ & $4.4 \pm 0.3^{\mathrm{a}}$ \\
\hline
\end{tabular}

Data are means \pm standard errors for each analyzed parameter. For each parameter and column, means followed by the same letters are not significantly different $\left(P \leq 0.05\right.$; Tukey's test). ${ }^{\dagger}$ IT, irrigation treatment; FW, fresh water; SW, secondary wastewater; TW, tertiary wastewater. 


\subsection{Polyphenolic Profile of the Artichoke Heads}

The effects, in terms of deviance (sum of square), of the growing season (GS), the irrigation treatments (IT), and their interaction, on the polyphenolic profile of the artichoke heads were investigated (Table S4, Supplementary Materials). GS factor significantly $(P \leq 0.05)$ affected the caffeoylquinic acid derivatives content (i.e., 5-CQA; 1,3 diCQA; 1,5-diCQA.; 3,4-diCQA; CafA) of main heads, secondary heads (with the exception of CafA), and processing heads (with the exception of 1,3-diCQA). Irrigation treatments significantly influenced all polyphenolic acids with the exception of apigenins Api-gl and Api-rut in the main heads and Lut-glr, Api-glr, and Api-rut in processing heads. No significant influence of IT was observed for the phenolic acid content in secondary heads. IT $\times$ GS interaction never showed significant effects; as a consequence, only the mean values related to main effect factors (GS and IT) will be discussed.

The content of the main caffeoylquinic acid derivatives of the artichoke heads is reported in Table 3. In general, 5-O-caffeoylquinic acid (5-CQA) was the most abundant compound within the evaluated caffeoylquinic derivatives, followed by 1,5-di-O-caffeoylquinic acid (1,5-diCQA), 3-O-caffeoylquinic acid (3-CQA), caffeic acid (CafA), and 1,3-di-O-caffeoylquinic acid (1,3-diCQA). In particular, the amount of 5-CQA represented about $39 \%, 54 \%$, and $85 \%$ of total caffeoylquinic acids for main, secondary, and processing heads, respectively. For all caffeoylquinic acids derivatives, the average values of the different head classes were higher in GS1 than GS2 (Table 3). As for the irrigation treatments, SW generally showed the highest values. In particular, for the main heads, SW was significantly higher with respect to both FW and TW for all caffeoylquinic acid derivatives, but not for CafA (Table 3). As for the processing heads, SW was always significantly higher than FW, and significantly higher than TW for 1,3-diCQA and CafA. Interestingly, the caffeoylquinic acid derivatives content of the secondary heads was not affected by the irrigation treatment.

The effects of IT on main flavones component (Apigenin 7-O-glucoside, Luteolin 7-O-glucoside, and Luteolin 7-O-glucuronide) and on trans-ferulic acid (TFA) of artichoke heads are reported in Table 4. Api-glc was the most abundant compound between other apigenins. Moreover, effects of treated wastewater were found only for Api-glc with the significant higher values under SW and TW compared to FW. IT factor did not significantly $(P>0.05)$ affect mean values of Api-glc for secondary heads class.

The concentrations of luteolin (Lut-glc and Lut-glr) were significantly influenced by wastewater irrigation. SW and TW showed significantly higher values of Lut-glc and Lut-glr in main and processing heads. Moreover, a significant difference for Lut-glr in processing heads was observed between SW and TW, showing SW the highest value. IT factor had no significant effect for the secondary heads class. Finally, SW showed the highest values for trans-ferulic acid (TFA) both in main and processing heads, while no differences were observed for the secondary heads. 
Table 3. Effects of the main experimental factors (growing season and irrigation treatment) on main caffeoylquinic acid derivatives (mg $100 \mathrm{~g}^{-1}$ d.w.) of main, secondary, and processing artichoke heads.

\begin{tabular}{|c|c|c|c|c|c|c|c|c|c|c|c|c|c|c|c|}
\hline & \multicolumn{3}{|c|}{ 5-CQA } & \multicolumn{3}{|c|}{ 1,3-diCQA } & \multicolumn{3}{|c|}{ 1,5-diCQA } & \multicolumn{3}{|c|}{ 3,4-diCQA } & \multicolumn{3}{|c|}{ CafA } \\
\hline & Main & Secondary & Processing & Main & Secondary & Processing & Main & Secondary & Processing & Main & Secondary & Processing & Main & Secondary & Processing \\
\hline \multicolumn{16}{|c|}{${\text { Growing season }(G S)^{+}}^{+}$} \\
\hline $\mathrm{GS}_{1}$ & $314.4 \pm 12.8^{\mathrm{a}}$ & $445.8 \pm 12.0^{\mathrm{a}}$ & $684.1 \pm 12.0^{\mathrm{a}}$ & $0.9 \pm 0.1^{\mathrm{a}}$ & $1.3 \pm 0.4^{\mathrm{a}}$ & $1.8 \pm 0.4^{\mathrm{a}}$ & $237.1 \pm 10.8^{\mathrm{a}}$ & $322.4 \pm 10.8^{\mathrm{a}}$ & $396.7 \pm 10.8^{\mathrm{a}}$ & $8.7 \pm 0.8^{\mathrm{a}}$ & $13.9 \pm 0.8^{\mathrm{a}}$ & $18.5 \pm 0.8^{\mathrm{a}}$ & $2.5 \pm 0.1^{b}$ & $2.6 \pm 0.3^{\mathrm{a}}$ & $3.1 \pm 0.2^{\mathrm{a}}$ \\
\hline $\mathrm{GS}_{2}$ & $276.3 \pm 11.2^{b}$ & $364.1 \pm 11.8^{b}$ & $594.9 \pm 11.8^{\mathrm{b}}$ & $0.7 \pm 0.2^{b}$ & $1.1 \pm 0.5^{\mathrm{a}}$ & $1.6 \pm 0.5^{\mathrm{a}}$ & $195.0 \pm 10.8^{b}$ & $265.7 \pm 10.8^{\mathrm{b}}$ & $338.5 \pm 10.8^{b}$ & $7.2 \pm 0.8^{b}$ & $10.7 \pm 0.8^{\mathrm{b}}$ & $15.0 \pm 0.8^{\mathrm{b}}$ & $2.7 \pm 0.1^{\mathrm{a}}$ & $2.2 \pm 0.3^{\mathrm{a}}$ & $2.5 \pm 0.1^{\mathrm{b}}$ \\
\hline \multicolumn{16}{|c|}{ Irrigation treatment $(I T) \ddagger$} \\
\hline FW & $281.5 \pm 10.5^{\mathrm{b}}$ & $406.8 \pm 11.4^{\mathrm{a}}$ & $557.1 \pm 11.4^{\mathrm{b}}$ & $0.7 \pm 0.1^{b}$ & $1.3 \pm 0.6^{\mathrm{a}}$ & $1.5 \pm 0.6^{b}$ & $176.1 \pm 10.8^{c}$ & $283.0 \pm 10.8^{\mathrm{a}}$ & $289.8 \pm 10.8^{b}$ & $6.8 \pm 0.8^{b}$ & $11.7 \pm 0.8^{\mathrm{a}}$ & $14.0 \pm 0.8^{\mathrm{b}}$ & $1.7 \pm 0.3^{b}$ & $2.4 \pm 0.2^{\mathrm{a}}$ & $2.4 \pm 0.1^{\mathrm{c}}$ \\
\hline sW & $319.2 \pm 11.0^{\mathrm{a}}$ & $402.8 \pm 10.6^{\mathrm{a}}$ & $713.2 \pm 10.6^{\mathrm{a}}$ & $1.1 \pm 0.1^{\mathrm{a}}$ & $1.2 \pm 0.4^{\mathrm{a}}$ & $2.0 \pm 0.4^{\mathrm{a}}$ & $261.1 \pm 10.8^{\mathrm{a}}$ & $293.0 \pm 10.8^{\mathrm{a}}$ & $412.8 \pm 10.8^{\mathrm{a}}$ & $10.0 \pm 0.8^{\mathrm{a}}$ & $13.4 \pm 0.8^{\mathrm{a}}$ & $18.2 \pm 0.8^{\mathrm{a}}$ & $2.3 \pm 0.1^{a}$ & $2.5 \pm 0.2^{\mathrm{a}}$ & $3.2 \pm 0.2^{\mathrm{a}}$ \\
\hline TW & $285.4 \pm 11.3^{\mathrm{b}}$ & $405.1 \pm 10.8^{\mathrm{a}}$ & $648.3 \pm 10.8^{a}$ & $0.7 \pm 0.1^{b}$ & $1.1 \pm 0.5^{\mathrm{a}}$ & $1.6 \pm 0.5^{b}$ & $211.0 \pm 10.8^{b}$ & $306.3 \pm 10.8^{\mathrm{a}}$ & $400.1 \pm 10.8^{\mathrm{a}}$ & $7.0 \pm 0.8^{b}$ & $11.8 \pm 0.8^{\mathrm{a}}$ & $17.8 \pm 0.8^{\mathrm{a}}$ & $2.7 \pm 0.2^{a}$ & $2.3 \pm 0.3^{a}$ & $2.7 \pm 0.1 \mathrm{~b}$ \\
\hline
\end{tabular}

Data are means \pm standard errors for each analyzed parameter. For each parameter and column, means followed by the same letters are not significantly different $(P \leq 0.05$; Tukey's test).

GS1, first growing season; GS2, second growing seasons. ${ }^{\ddagger}$ IT, irrigation treatment; FW, fresh water; SW secondary wastewater; TW, tertiary wastewater. 5-CQA: 5-O-caffeoylquinic acid (chlorogenic Ac.); 1,3-diCQA: 1,3 di-O-caffeoylquinic acid (cynarin); 1,5-diCQA: 1,5-di-O-caffeoylquinic Acid; 3,4-diCQA: 3,4-di-O-caffeoylquinic Acid; CafA: caffeic acid. 
Table 4. Effects of the main experimental factors (growing season and irrigation treatment) on apigenin and luteolin components and their conjugates, and trans-ferulic acid content (mg $100 \mathrm{~g}^{-1} \mathrm{~d}$.w.) of main, secondary, and processing artichoke heads.

\begin{tabular}{|c|c|c|c|}
\hline Irrigation Treatment $^{\dagger}$ & & Api-glc & \\
\hline & Main & Secondary & Processing \\
\hline FW & $26.1 \pm 0.5^{b}$ & $34.2 \pm 1.4^{\mathrm{a}}$ & $34.0 \pm 1.4^{\mathrm{C}}$ \\
\hline SW & $34.9 \pm 1.0^{\mathrm{a}}$ & $34.9 \pm 0.6^{\mathrm{a}}$ & $43.9 \pm 0.6^{\mathrm{a}}$ \\
\hline \multirow[t]{3}{*}{ TW } & $31.5 \pm 1.3^{\mathrm{a}}$ & $32.6 \pm 0.8^{a}$ & $37.9 \pm 0.8^{b}$ \\
\hline & & Lut-glc & \\
\hline & Main & Secondary & Processing \\
\hline FW & $2.2 \pm 0.5^{b}$ & $3.4 \pm 0.4^{\mathrm{a}}$ & $3.1 \pm 0.2^{b}$ \\
\hline SW & $3.1 \pm 0.2^{\mathrm{a}}$ & $3.1 \pm 0.2^{\mathrm{a}}$ & $3.5 \pm 0.3^{\mathrm{a}}$ \\
\hline \multirow[t]{3}{*}{ TW } & $3.0 \pm 0.3^{a}$ & $3.2 \pm 0.3^{a}$ & $3.7 \pm 0.2^{\mathrm{a}}$ \\
\hline & & Lut-glr & \\
\hline & Main & Secondary & Processing \\
\hline FW & $6.5 \pm 0.4^{b}$ & $10.7 \pm 0.5^{a}$ & $12.7 \pm 0.3^{b}$ \\
\hline SW & $10.1 \pm 0.2^{\mathrm{a}}$ & $10.0 \pm 0.4^{\mathrm{a}}$ & $15.3 \pm 0.4^{\mathrm{a}}$ \\
\hline \multirow[t]{3}{*}{ TW } & $8.3 \pm 0.3^{a b}$ & $10.9 \pm 0.3^{a}$ & $12.6 \pm 0.5^{b}$ \\
\hline & & TFA & \\
\hline & Main & Secondary & Processing \\
\hline FW & $22.6 \pm 1.4^{\mathrm{ab}}$ & $25.5 \pm 2.3^{a}$ & $25.5 \pm 2.3^{b}$ \\
\hline SW & $27.2 \pm 1.2^{\mathrm{a}}$ & $30.5 \pm 4.4^{\mathrm{a}}$ & $31.5 \pm 2.4^{\mathrm{a}}$ \\
\hline TW & $21.6 \pm 2.3^{b}$ & $27.4 \pm 1.5^{\mathrm{a}}$ & $26.1 \pm 1.5^{b}$ \\
\hline
\end{tabular}

Data are means \pm standard errors for each analyzed parameter. For each parameter and column, means followed by the same letters are not significantly different $\left(P \leq 0.05\right.$; Tukey's test). ${ }^{\dagger} \mathrm{FW}$, fresh water; SW secondary wastewater; TW, tertiary wastewater. Api-glc: Apigenin 7-O-glucoside; Lut-glc: Luteolin 7-O-glucoside; Lut-glr: Luteolin 7-O-glucuronide; TFA: 4-hydro-3-methylcinnamale (trans-ferulic acid).

\subsection{Multivariate Analysis on Qualitative Parameters}

The results of the analysis of variance previously reported showed the effects of the experimental factor, irrigation treatment combined with growing season, on each artichoke qualitative parameter considered individually. The adopted multivariate approach (stepwise discriminant analysis, SDA) allowed us to integrate the above-reported data and to evaluate which of the qualitative variables, simultaneously analyzed, mainly contributed to the separation of the experimental groups. SDA was performed considering as discriminating sources two experimental factors: The irrigation treatment and the head class. Each experimental factor exhibited strong significant differences for all multivariate tests performed (Table S5). Therefore, it was necessary for each experimental factor, through the stepwise procedure, to determine which of the qualitative parameter(s) played the most important role in giving rise to the group differences. The selected parameters, showing a significant $F$ ratio value $(P \leq 0.05)$, are reported in Table 5 . 
Table 5. Artichoke qualitative parameters selected by stepwise discriminant analysis applied to irrigation treatment and head class.

\begin{tabular}{cccccc}
\hline Parameter Selected & F Ratio Value & Prob F $^{+}$ & Parameter Selected & F Ratio Value & Prob F $^{\dagger}$ \\
\hline Irrigation treatment & & \multicolumn{5}{c}{ Heads classes } \\
Chloride & 3.9 & 0.03 & Dry matter & 3.9 & 0.03 \\
Potassium & 10.0 & 0.0003 & Edible part & 44.7 & $<0.0001$ \\
Copper & 3.1 & 0.05 & Sodium & 35.2 & $<0.0001$ \\
Zinc & 10.1 & 0.00027 & Magnesium & 8.5 & $<0.0008$ \\
TFA & 19.8 & $<0.0001$ & 5-CQA & 5.8 & 0.005 \\
- & - & - & TFA & 5.6 & 0.007 \\
- & - & - & 1,5-diCQA & 3.2 & 0.05 \\
\hline
\end{tabular}

5-CQA: 5-O-caffeoylquinic acid (chlorogenic acid); 1,5-diCQA: 1,5-di-O-caffeoylquinic acid TFA:

4-hydro-3-methylcinnamale (trans-ferulic acid); ${ }^{\dagger}$ Prob F, F-ratio significance.

As for the irrigation treatment, the discriminant analysis selected five qualitative parameters (chloride, potassium, copper, zinc, and TFA) showing the best discrimination among the groups (FW, SW, and TW). In particular, TFA and potassium were the first qualitative parameters added in SDA procedure (F ratio $=19.8$ and 10.0, respectively; $P<0.001)$, while the last was the copper $(\mathrm{F}$ ratio $=3.1$; $P<0.05)$. As for the head class, seven qualitative parameters were identified (dry matter, edible part, sodium, magnesium, 5-CQA, TFA, and 1,5-diCQA); the edible part percentage and sodium content were the first two qualitative parameters added in SDA procedure ( $\mathrm{F}$ ratio $=44.7$ and 35.2, respectively; $P<0.001$ ), while the last was the 1,5-diCQA content (F ratio $=3.1 ; P<0.05$ ). The mineral component of the heads, such as chloride, potassium, copper, and zinc content, had a greater weight in the separation of FW, SW, and TW. On the other hand, the polyphenolic 5-CQA, TFA, and 1,5-diCQA had a greater weight in the separation of the head class groups (main, secondary, and processing). Moreover, the TFA content of the heads was related both to the irrigation water type and to the different head classes.

The discriminant analysis was performed on the five parameters selected for the irrigation treatment by the stepwise procedure and on the seven for the head classes. Table 6 shows the standardized coefficients (scores) for the first two canonical axes (CA1-2). Concerning the irrigation treatment, both the canonical axes were significantly affected (high absolute value of the standardized canonical coefficients and significant value of the correlation coefficients) by the five parameters selected with the exception of the chloride for CA1 and of the copper for CA2. CA1 and CA2 axis accounted for $80.0 \%$ and $20.0 \%$, respectively. Concerning the head class, CA1, accounting for $88.5 \%$ of the total variance, was affected by all the seven parameters selected with the exception of the magnesium, while the CA2, accounting for $11.5 \%$ of the total variance, was significantly affected by sodium and magnesium only.

Similar considerations can be made taking into account the biplot graph and considering the relative length and direction of the vectors (Figures 2 and 3). The results of the multivariate analysis applied to irrigation treatment factor (Figure 2) showed that the selected five parameters by SDA procedure allowed a significant differentiation among the irrigation treatment levels. In particular, TW was more characterized by chloride, potassium, and copper content, while SW by zinc and TFA content. Regarding the head class, the seven selected parameters by SDA procedure allow a significant differentiation among the heads group (Figure 3); in particular, the polyphenolic content (i.e., 5-CQA, TFA, and 1,5-diCQA) better characterized the processing heads class. 
Table 6. Standardized coefficients (scores) and Pearson's correlation coefficient for the first two canonical axes $\left(\mathrm{CA}_{1-2}\right)$, considering the different qualitative parameters of artichoke heads as selected by stepwise discriminant analysis (SDA). The corresponding percentages of accounted variation are also reported.

\begin{tabular}{ccccc}
\hline Parameters & \multicolumn{2}{c}{ Standardized Coefficients } & \multicolumn{2}{c}{ Pearson's Correlation Coefficients } \\
\hline Irrigation treatment & $\mathrm{CA}_{1}$ & $\mathrm{CA}_{2}$ & $\mathrm{CA}_{1}$ & $\mathrm{CA}_{2}$ \\
\hline Chloride & 0.198 & 0.635 & $0.18 \mathrm{~ns}$ & $0.80^{* * *}$ \\
Potassium & 0.532 & 0.600 & $0.47^{* *}$ & $0.62^{* *}$ \\
Copper & 0.381 & 0.276 & $0.76^{* * *}$ & $0.11 \mathrm{~ns}$ \\
Zinc & 0.827 & -0.721 & $0.75^{* * *}$ & $-0.62^{* *}$ \\
TFA & 0.647 & -0.996 & $0.53^{* *}$ & $-0.49^{* *}$ \\
\% variance & $\mathbf{8 0 . 0}$ & $\mathbf{2 0 . 0}$ & & \\
explained & & & & \\
Head class & & & $0.38^{*}$ & $0.10 \mathrm{~ns}$ \\
Dry matter & 0.366 & 0.263 & $-0.89^{* * *}$ & $-0.76^{* * *}$ \\
Edible part & -1.328 & 0.497 & $0.42^{* *}$ & $0.45^{* *}$ \\
Sodium & 0.396 & -1.119 & $0.29 \mathrm{~ns}$ & $0.01 \mathrm{~ns}$ \\
Magnesium & 0.197 & 0.619 & $0.92^{* * *}$ & $0.29 \mathrm{~ns}$ \\
5-CQA & 0.585 & 0.003 & $0.46^{* *}$ & $0.20 \mathrm{~ns}$ \\
TFA & 0.521 & 0.281 & $0.70^{* * *}$ & \\
1,5-diCQA & 0.468 & 0.265 & & \\
\% variance & $\mathbf{8 8 . 5}$ & $\mathbf{1 1 . 5}$ & & \\
explained & & & \\
\hline$*$ corr & & & \\
\hline
\end{tabular}

*, correlation significant at the 0.05 level $(p$-value 0.05$) ;{ }^{* *}$, correlation significant at the 0.01 level $(p$-value 0.01$) ; * * *$, correlation significant at the 0.001 level ( $p$-value 0.001$)$; ns, not significant.

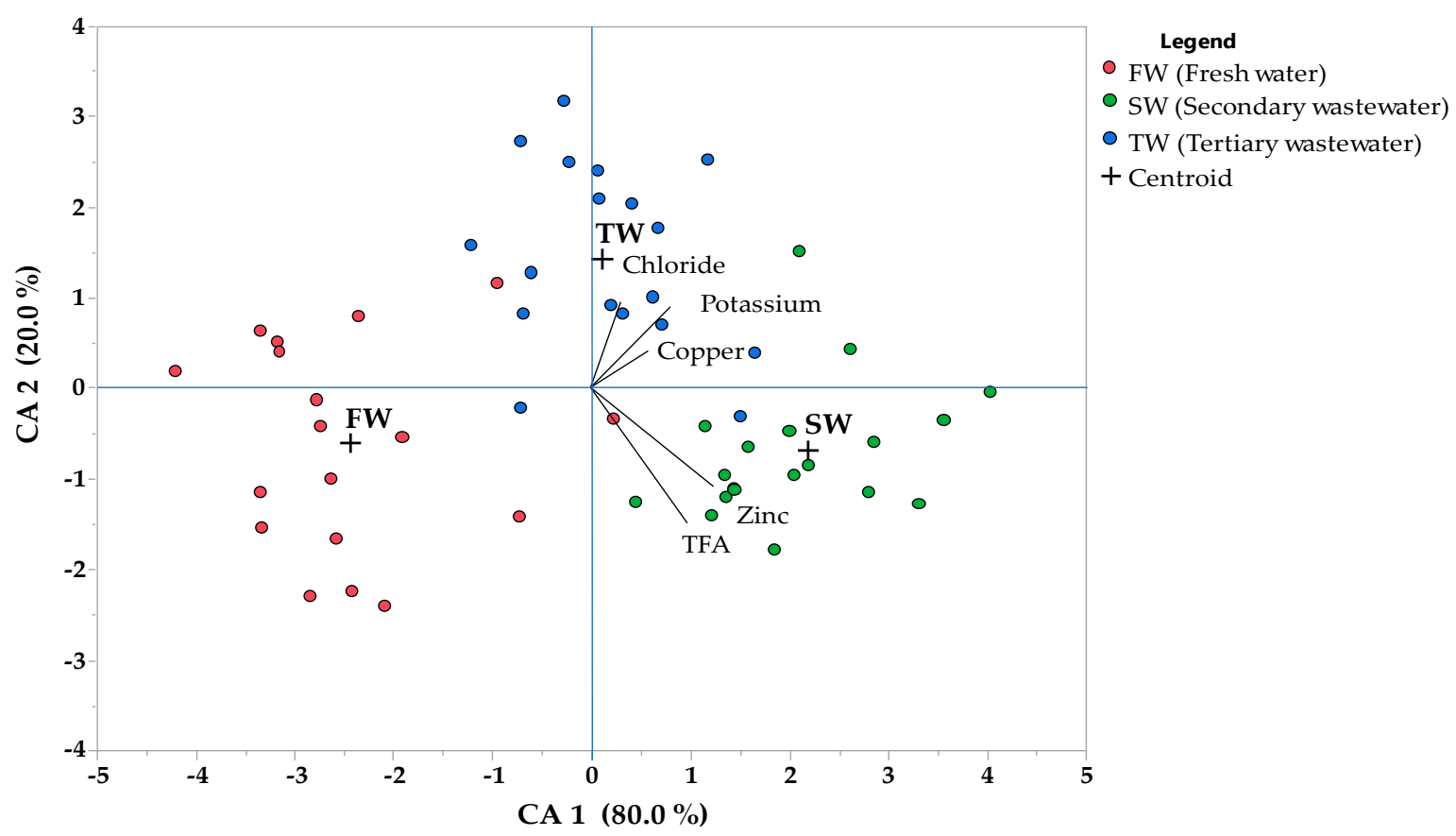

Figure 2. Stepwise discriminant analysis biplot of the quality parameters of artichoke heads considering the irrigation factor as the discriminant variables. For each data point, the irrigation treatment code is included. TFA: 4-hydro-3-methylcinnamale (Trans-ferulic acid). 


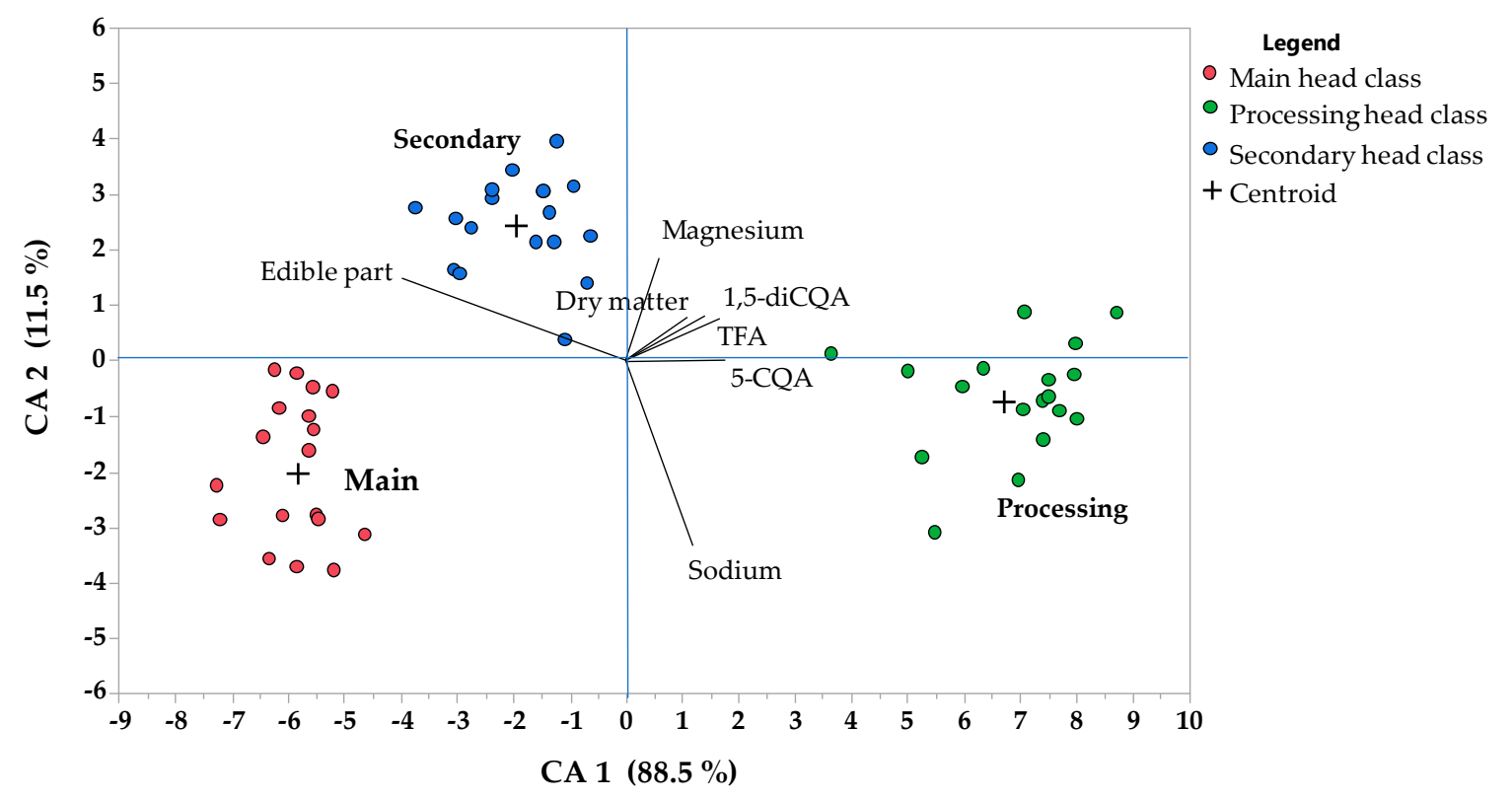

Figure 3. Stepwise discriminant analysis biplot of the quality parameters of artichoke heads considering the head class factor as the discriminant variables. For each data point, the head class names are included. 5-CQA: 5-O-caffeoylquinic acid (chlorogenic acid); 1,5-diCQA: 1,5-di-O-caffeoylquinic acid.

\section{Discussion}

The aim of this study was to evaluate the effects of the irrigation based on the use of two different municipal wastewaters (secondary-treated wastewater and tertiary-treated wastewater) on protein content, mineral elements, and polyphenolic profile of different classes of globe artichoke (main, secondary, and processing heads). Some studies concerning the effect of treated wastewaters on the yield, quality, and microbiological properties of main horticultural crops have already been reported. However, to the best of our knowledge no in-depth characterization is available on the quality aspects, in particular, polyphenolic profile, of the artichoke grown in Mediterranean area under wastewater irrigations regimes.

\subsection{Proximate Composition and Mineral Profile of the Artichoke Heads}

Because only the central portion of the artichoke heads is consumed, the ratio edible fraction/total head produced is an important qualitative parameter. Both SW and TW treatments caused an increase of the percentage of the edible part for the main and processing head classes likely due to the higher weights obtained in a previous study under SW and TW treatments compared with FW [3]. This result is in agreement with Mauro et al. (2011) [40], which reported an increase of weight heads together with an increase of edible fraction for three globe artichoke genotypes ('Violetto di Sicilia', 'Harmony', and 'Madrigal'). Taking into account that main heads represents the main marketable class, very appreciated by consumers, the increase of this qualitative parameter may lead to an increase in its commercial value. The percentage of the edible part of the artichoke heads observed in this study (about $35 \%$ on fresh weight) was generally in accordance with data reported by Bonasia et al. (2010) [18] for the cultivar ('Violetto di Provenza') in Southern Italy.

The protein content of head increased under treated wastewater irrigation, especially for processing heads (about 15\%). This increment can be attributed to the higher amount of nitrogen supplied to the soil by the application of the wastewater that was on average $95 \mathrm{~kg} \mathrm{ha}^{-1}$ and $66 \mathrm{~kg} \mathrm{ha}^{-1}$ for the SW and TW, respectively (Table 1). Moreover, the nitrogen added by using SW and TW was partitioned along the crop cycle and precisely at each irrigation time. Saleh et al. (2016) [41] reported that the effect of nitrogen fertilization on protein head content depends both on total amount of nitrogen applied and on the application timing during the crop cycle according to the plant nitrogen request. Thus, the 
use of wastewaters could be considered a useful tool to improve the quality performances of the crop, ensuring, at the same time, a more environmentally friendly nitrogen fertilization. This result is of particular relevance since in Mediterranean regions, globe artichoke fertilization is still empirically oriented toward nitrogen overdressing [16]. This practice has been demonstrated to cause $\mathrm{N}$ pollution and food safety deterioration $[42,43]$.

Surprisingly, few studies are reported on mineral uptake and accumulation in globe artichoke crops irrigated with treated wastewater. The number of mineral elements present in vegetable crops is a crucial point since, despite improvements in crop yield, malnutrition is still an actual problem in several world areas [44]. From this point of view, it appears very interesting the significant increase of potassium, sodium, and magnesium content observed in the main and processing heads under SW and TW irrigation compared to FW. Potassium was the most abundant macroelement in artichoke, as previously reported $[13,45,46]$.

A significant increase was observed also for the mineral microelements in main and processing heads irrigated with SW and TW. However, their concentration remained below the limits specified in the European [47] and international guidelines for vegetables used for human consumption [48].

Except for calcium and magnesium, the mineral content in artichoke heads classes was significantly correlated $(P \leq 0.05)$ with their content in the irrigation waters (Table 7$)$. Usually, higher values of the Pearson's coefficient have been detected for main and processing classes compared to secondary. This could be due to the higher amount of irrigation water supplied (1850 and 950, for the main and the processing, respectively, vs. $350 \mathrm{~m}^{3} \mathrm{ha}^{-1}$ for the secondary) and, consequently, to a higher intake of minerals within the artichoke heads. These data are in agreement with results reported by Achah et al. (2014) [49], who found a close relationship between iron content in the irrigation water and iron content of the vegetable samples. On the other hand, Al-Lahham et al. (2007) [50] reported increased concentrations of manganese and iron in the soil correlated with the high concentrations of these minerals in the wastewater used for irrigation. The absence of significant correlation between calcium and magnesium heads content and their content in irrigation waters could be due both to the complex interactions among mineral elements in the soil with consequent different uptake by plants, and to the different elements translocation within the plant (roots, leaves, and heads) [46].

Table 7. Pearson's correlation coefficient values between mineral profile of heads content by artichoke classes and irrigation water content.

\begin{tabular}{cccccccccccccc}
\hline Head Classes & $\mathrm{NO}_{3}-\mathbf{N}$ & $\mathbf{P O}_{4}-\mathbf{P}$ & $\mathbf{S O}_{4}{ }^{-2}$ & $\mathbf{C l}^{-}$ & $\mathbf{K}$ & $\mathbf{N a}$ & $\mathbf{C a}$ & $\mathbf{M g}$ & $\mathbf{F e}$ & $\mathbf{C u}$ & $\mathbf{Z n}$ & $\mathbf{N i}$ \\
\hline Main & $0.85^{* * *}$ & $0.54^{* *}$ & $0.18 \mathrm{~ns}$ & $0.72^{* * *}$ & $0.59^{* *}$ & $0.80^{* * *}$ & $-0.33 \mathrm{~ns}$ & $-0.02 \mathrm{~ns}$ & $0.6^{* * *}$ & $0.85^{* * *}$ & $0.82^{* * *}$ & $0.83^{* * *}$ \\
\hline Secondary & $0.38^{*}$ & $0.12 \mathrm{~ns}$ & $0.34^{*}$ & $0.51^{* *}$ & $0.43^{*}$ & $0.31^{*}$ & $0.18 \mathrm{~ns}$ & $-0.12 \mathrm{~ns}$ & $0.43^{*}$ & $0.37^{*}$ & $0.59^{* *}$ & $0.19 \mathrm{~ns}$ \\
\hline Processing & $0.55^{* *}$ & $0.11 \mathrm{~ns}$ & $-0.09 \mathrm{~ns}$ & $0.70^{* * *}$ & $0.73^{* * *}$ & $0.80^{* * *}$ & $-0.04 \mathrm{~ns}$ & $0.03 \mathrm{~ns}$ & $0.63^{* *}$ & $0.56^{* *}$ & $0.57^{* *}$ & $0.77^{* *}$ \\
\hline
\end{tabular}

$\mathrm{ns}$, correlation not significant $(P$-value $>0.05) .{ }^{*}$ correlation significant at the 0.05 level $(P$-value $\leq 0.05) .{ }^{* *}$ correlation significant at the 0.01 level $(P$-value $\leq 0.01)$. ${ }^{* * *}$ correlation significant at the 0.001 level $(P$-value $\leq 0.001)$.

\subsection{Phenolic Profile of the Artichoke Heads}

In agreement with several researches performed on artichoke crop [13,15,21,23,35,51], the 5-CQA and the 1,5-diCQA, were the most abundant compound within the evaluated caffeoylquinic derivatives, followed by 3-CQA and finally 1,3-diCQA. In particular, the amount of 5-CQA represented about 70\%, $50 \%$, and $86 \%$ of total caffeoylquinic acids for main, secondary, and processing heads, respectively.

Under our experimental conditions, the increase of main caffeoylquinic acid derivatives observed in GS1 could be due to the higher temperatures and solar radiation that characterized the year (GS1) compared to GS2. These differences between GS1 and GS2 were found especially during the growth period from September to April $\left(\Delta \geq 2.0^{\circ} \mathrm{C}\right.$ and $\left.\Delta \geq 35 \mathrm{cal} \mathrm{cm}^{-2} \mathrm{die}^{-1}\right)$. Also, Pandino et al. (2013) [26], in a study carried out in a geographic area very similar to ours, reported that the artichoke plant responded to higher solar radiation levels with a marked increase in the content of caffeoylquinic acids (predominantly 5-O-caffeoylquinic and 1,5-O-di-caffeoylquinic acid) probably due to the higher flux of photosynthetically generated electrons and therefore an increased presence of reactive oxygen species. 
Thus, our results confirmed the important effect of the climatic conditions on the artichoke polyphenolic profiles. Generally, crops react to the climatic-induced changes modifying the biosynthesis of their secondary metabolites, such as flavonoids and hydroxycinnamates [26,35,46,52].

Moreover, in our experimental conditions, the caffeoylquinic acid derivatives content varied in artichoke heads in relation to different harvesting time represented by the different classes of heads (main, secondary, processing). In particular, the 5-CQA and 1,5-diCQA in processing heads class were about 2 times higher than in the main heads class. Our findings are in agreement with other study [26] performed on commercial cultivar 'Violetto di Sicilia' for evaluating the influence of harvesting time on the polyphenolic profile. The authors showed that the harvesting time, ranging from February to April, was able to maximize the polyphenolic content in artichoke heads.

A significant effect of irrigation with wastewater on polyphenolic profile was observed only for main and processing heads. It was probably due to the higher irrigation water amount supplied to this head's category plants. We also observed a different effect of the wastewater types on the polyphenolic compounds. In particular, SW significantly increased the caffeoylquinic acid derivatives, while both SW and TW caused an increase of Apigenin 7-O-glucoside and Luteolin 7-O-glucoronide. These results are relevant since apigenin, as well as other flavones, is not distributed widely in food plants, and globe artichoke represents a significant dietary source of this compound and its conjugates [13].

The increase observed for these compounds could probably be due to a higher nitrogen availability, since that element was supplied also by wastewater irrigation during the crop cycle (Table 1). Our results are in accordance with Ma et al. (2015) [53] who reported an increase of total phenolic content in winter wheat when $\mathrm{N}$-fertilization was applied, and in artichoke, on which a balanced nitrogen fertilizer positively affects the polyphenolic profile and the antioxidant activity of the two cultivars 'Apollo' and 'Tema 2000' [51]. In particular, the authors reported that the greatest accumulation of both caffeoylquinic acids and flavonoids occurred in plants grown under balanced nitrogen fertilizer regime $\left(200 \mathrm{~kg} \mathrm{ha}^{-1} \mathrm{~N}\right)$ with respect to an excessive fertilizer regime $\left(500 \mathrm{~kg} \mathrm{ha}^{-1} \mathrm{~N}\right)$. Under our experimental conditions, the total nitrogen applied, including the rate coming from the use of the wastewater, was 274 and $246 \mathrm{~kg} \mathrm{ha}^{-1}$, for SW and TW irrigation treatments, respectively. However, other studies [46,54-56] reported an inverse relationship between plant nitrogen availability and carbon-based secondary metabolite levels (e.g., terpenes, phenols, and other compounds).

The increase in polyphenolic acids achieved under our experimental condition is extremely interesting if we consider the artichoke as a functional food according to the definition of the European Commission on Functional Food Science in Europe (FuFoSe) [57]. Indeed, phenolic compounds are reported to exert beneficial effects in the treatment of hepato-biliary diseases, hyperlipidaemia, dropsy, rheumatism, and cholesterol metabolism [15]. These broad therapeutic indications cannot be ascribed to a single compound, but to several active compounds providing additive or synergistic pharmacologic effects, including mono-caffeoylquinic and di-caffeoylquinic acids, and flavonoids such as luteolin and its 7-O-glucoside [23,58-61].

\section{Conclusions}

This research activity revealed interesting results, which can be summarized as follows. Secondary (SW) and tertiary wastewater (TW) positively affected the head quality, in terms of protein content and edible part percentage. Considering that main heads represent the most important class for marketable yield, very appreciated by consumers, an increase of this qualitative parameter may lead to an increase in its market value. Both SW and TW treatments significantly affected the mineral profile (macro and microelements) of the main and processing heads, showing higher values. Higher temperatures and solar radiation that characterized GS1 probably caused the observed increase of the main caffeoylquinic acid derivatives. Moreover, SW increased the caffeoylquinic acid derivatives and trans-ferulic acid content, while both SW and TW increased the flavones content. The increase achieved for protein content and polyphenolic acids could be attributed to the amount of nitrogen supplied to the soil by the application of the wastewater and partitioned along the crop cycle at each irrigation time. 
Finally, the adopted multivariate approach showed that, in our experimental conditions, the effect of TW was more linked to the heads content of chloride, potassium, and copper, while the effect of SW by zinc and TFA heads content. Regarding the heads class, the processing head was the class more characterized by polyphenolic contents such as 5-CQA, 1,5-diCQA, and TFA. The positive effects of the use of wastewater on the qualitative parameters of artichoke that we found, could increase the degree of social acceptability of this type of water as well as the commercial value of artichoke grown in Mediterranean area.

Supplementary Materials: The following are available online at http://www.mdpi.com/2073-4395/10/1/53/s1. Table S1. Monthly rainfall, temperature (maximum, minimum and average) and solar radiation recorded over the two artichoke growing seasons (GS1 and GS2). The sampling months of the artichoke heads are shown in bold. Table S2: Sum of square of the two factors (GS and IT) and their interaction (GS $\times$ IT) relative to the proximate components and edible part percentage. Table S3: Sum of square of the two factors (GS and IT) and their interaction $(\mathrm{GS} \times \mathrm{IT})$ relative to the mineral profile of the artichoke heads. Table S4: Sum of square of the two factors (GS and IT) and their interaction $(\mathrm{GS} \times \mathrm{IT})$ relative to the polyphenolic profile of the artichoke heads. Table S5. Multivariate tests to verify the significance between the different groups (irrigation treatment and heads classes) by discriminant analysis procedure.

Author Contributions: Conceptualization, G.G. and M.M.G. methodology, G.G. validation, G.G, M.M.G., and M.F. formal analysis, A.G., G.G., and M.M.G. investigation, A.G., F.C., M.F. writing-original draft preparation, A.G. writing-review and editing, G.G. and M.M.G. visualization, A.G. and F.C. supervision, G.G. and M.M.G. project administration, G.G. and M.M.G. All authors have read and agreed to the published version of the manuscript.

Funding: This research received no external funding.

Acknowledgments: This study was part of the Project “Technology and Process Innovations for Irrigation Re-use of Treated Municipal and Agro-industrial Wastewaters to Achieve Sustainable Water Resources Management" (In.Te.R.R.A contract No. 01-01480), which was co-funded by Ministero dell'Istruzione, dell'Università e della Ricerca within the Italian "PON/Ricerca e Competitività 2007-2013" Programme. We would like to show our gratitude to Dr. Eugenio Nardella for his skilful technical assistance during the experimental trials.

Conflicts of Interest: The authors declare no conflict of interest.

\section{References}

1. Giuliani, M.M.; Nardella, E.; Gagliardi, A.; Gatta, G. Deficit irrigation and partial root-zone drying techniques in processing tomato cultivated under Mediterranean conditions. Sustainability 2017, 9, 2197. [CrossRef]

2. Hassanein, R.A.; Hashem, H.A.; Hashem El-Deep, M.; Shouman, A. Soil contamination with heavy metal and its effect on growth, yield and physiological responses of vegetable crop plants (turnip and lettuce). J. Stress Physiol. Biochem. 2013, 9, 145-162.

3. Gatta, G.; Libutti, A.; Beneduce, L.; Gagliardi, A.; Disciglio, G.; Lonigro, A.; Tarantino, E. Reuse of treated municipal wastewater for globe artichoke irrigation: Assessment of effects on morpho-quantitative parameters and microbial safety of yield. Sci. Hortic. 2016, 213, 55-65. [CrossRef]

4. Benitez, E.; Romero, M.; Gomez, M.; Gallardolaro, F.; Nogales, R. Biosolid and biosolid ash as sources of heavy metals in plant-soil system. Water Air Soil Poll. 2001, 132, 75-87. [CrossRef]

5. Abdallah, A.; Bader, A. Comparison between the irrigation qualities of conventional tertiary and UF $+\mathrm{RO}$ advanced treated wastewaters. J. Agric. Sci. 2011, 2, 526-532. [CrossRef]

6. Kocak, S.; Tokusoglu, O.; Aycan, S. Some heavy metal and trace essential element detection in canned vegetable foodstuffs by differential pulse polarography (DPP). Electron. J. Environ. Agric. Food Chem. 2005, 4, 871-878.

7. Gatta, G.; Gagliardi, A.; Disciglio, G.; Lonigro, A.; Francavilla, M.; Tarantino, E.; Giuliani, M.M. Irrigation with treated municipal wastewater on artichoke crop: Assessment of soil and yield heavy metal content and human risk. Water 2018, 10, 225. [CrossRef]

8. Nazar, R.; Iqbal, N.; Masood, A.; Khan, M.I.R.; Syeed, S.; Khan, N.A. Cadmium toxicity in plants and role of mineral nutrients in its alleviation. Am. J. Plant Sci. 2012, 3, 1476-1489. [CrossRef]

9. Rattan, R.K.; Datta, S.P.; Chhonkar, P.K.; Suribabu, K.; Singh, A.K. Long-term impact of irrigation with sewage effluents on heavy metal content in soils, crops and groundwater: A case study. Agric. Ecosyst. Environ. 2005, 109, 310-322. [CrossRef] 
10. Scoccianti, V.; Crinelli, R.; Tirillini, B.; Mancinelli, V.; Speranza, A. Uptake and toxicity of Cr (III) in celery seedlings. Chemosphere 2006, 64, 1695-1703. [CrossRef]

11. Nada, E.; Ben, A.F.; Rhouma, A.; Ben, R.B.; Mezghani, I.; Boukhris, M. Cadmium-induced growth inhibition and alteration of biochemical parameters in almond seedlings grown in solution culture. Acta Physiol. Plant. 2007, 29, 57-62. [CrossRef]

12. Lonigro, A.; Catalano, M.; Rubino, P. Impiego in agricoltura di acque reflue urbane depurate nel rispetto della sostenibilità ambientale. Ital. J. Agron. 2007, 2, 217-259. [CrossRef]

13. Pandino, G.; Lombardo, S.; Mauromicale, G. Mineral profile in globe artichoke as affected by genotype, head part and environment. J. Sci. Food Agric. 2011, 91, 302-308. [CrossRef] [PubMed]

14. Pandino, G.; Courts, F.L.; Lombardo, S.; Mauromicale, G.; Williamson, G. Caffeoylquinic acids and flavonoids in the immature inflorescence of globe artichoke, wild cardoon and cultivated cardoon. J Agric. Food Chem. 2010, 58, 1026-1031. [CrossRef] [PubMed]

15. Lattanzio, V.; Kroon, P.A.; Linsalata, V.; Cardinali, A. Globe artichoke: A functional food and source of nutraceutical ingredients. J. Funct. Foods 2009, 1, 131-144. [CrossRef]

16. Ierna, A.; Mauro, R.P.; Mauromicale, G. Improved yield and nutrient efficiency in two globe artichoke genotypes by balancing nitrogen and phosphorus supply. Agron. Sustain. Dev. 2012, 32, 773-780. [CrossRef]

17. FAO 2016. Food and Agriculture Organization of the United Nations. Available online: http://www.faostat. fao.org (accessed on 14 October 2018).

18. Bonasia, A.; Conversa, G.; Lazzizera, C.; Gambacorta, G.; Elia, A. Morphological and qualitative characterisation of globe artichoke head from new seed-propagated cultivars. J. Sci. Food Agric. 2010, 90, 2689-2693. [CrossRef]

19. Ceccarelli, N.; Curadi, M.; Picciarelli, P.; Martelloni, L.; Sbrana, C.; Giovannetti, M. Globe artichoke as a functional food. Med. J. Nutr. Metab. 2010, 3, 197-201. [CrossRef]

20. Pandino, G.; Lombardo, S.; Mauromicale, G.; Williamson, G. Profile of polyphenols and phenolics acids in bracts and receptacles of globe artichoke (Cynara cardunculus var scolymus) germplasm. J. Food. Compos. Anal. 2011, 24, 148-153. [CrossRef]

21. Lombardo, S.; Pandino, G.; Ierna, A.; Mauromicale, G. Variation of polyphenols in a germplasm collection of globe artichoke. Food Res. Int. 2012, 46, 544-551. [CrossRef]

22. Nicoletto, C.; Santagata, S.; Tosini, F.; Sambo, P. Qualitative and healthy traits of different Italian typical artichoke genotypes. J. Food Res. 2013, 11, 108-113. [CrossRef]

23. Schütz, K.; Kammerer, D.; Carle, R.; Schieber, A. Identification and quantification of caffeoylquinic acids and flavonoide from artichoke (Cynara scolymus L.) heads, juice, and pomace by HPLC-DAD-ESI/MSn. J. Agric. Food Chem. 2004, 52, 4090-4096. [CrossRef] [PubMed]

24. Lombardo, S.; Pandino, G.; Mauromicale, G.; Knodler, M.; Carle, R.; Schieber, A. Influence of genotype, harvest time and plant part on polyphenolic composition of globe artichoke [Cynara cardunculus L. var. scolymus (L.) Fiori]. Food Chem. 2010, 119, 1175-1181. [CrossRef]

25. Pavlica, S.; Gebhardt, R. Protective effects of ellagic and chlorogenic acids against oxidative stress in PC12 cells. Free Radic. Res. 2005, 39, 1377-1390. [CrossRef] [PubMed]

26. Pandino, G.; Lombardo, S.; Lo Monaco, A.; Mauromicale, G. Choice of time of harvest influences the polyphenol profile of globe artichoke. J. Funct. Foods 2013, 5, 1822-1828. [CrossRef]

27. Pollice, A.; Lopez, A.; Laera, G.; Rubino, P.; Lonigro, A. Tertiary filtered municipal wastewater as alternative water source in agriculture: A field investigation in Southern Italy. Sci. Total Environ. 2004, 324, 201-210. [CrossRef]

28. Beneduce, L.; Gatta, G.; Bevilacqua, A.; Troiano, E.; Spano, G. Impact of the reusing of food manufacturing wastewater for irrigation in a closed system on the microbiological quality of the food crops. Int. J. Food Microbiol. 2017, 260, 51-58. [CrossRef]

29. Available online: www.consorzio.fg.it (accessed on 15 November 2014).

30. AOAC. Official Method of Analysis; No. 934.06; Association of Official Analytical Chemists: Washington, DC, USA, 1990.

31. Dolciotti, I.; Mambelli, S.; Grand, S.; Venturi, G. Comparison of two Sorghum genotypes for sugar and fiber production. Ind. Crops Prod. 1998, 7, 265-272. [CrossRef]

32. De Clerk, J. Course de Brasserie, 2nd ed.; Universitè Catholique de Louvain: Louvain-la-Neuve, Belgium, 1963. 
33. Renna, M.; Gonnella, M.; Giannino, D.; Santamaria, P. Quality evaluation of cook-chilled chicory stems (Cichorium intybus L., Catalogna group) by conventional and sous vide cooking methods. J. Sci. Food Agric. 2014, 94, 656-665. [CrossRef]

34. US-EPA. Risk Assessment Guidance for Superfund; EPA/540/1-89/002, OSWER; USEPA: Washington, DC, USA, 1989.

35. Rouphael, Y.; Colla, G.; Graziani, G.; Ritieni, A.; Cardarelli, M.; De Pascale, S. Phenolic composition, antioxidant activity and mineral profile in two seed-propagated artichoke cultivars as affected by microbial inoculants and planting time. Food Chem. 2017, 234, 10-19. [CrossRef]

36. Pandino, G.; Lombardo, S.; Mauromicale, G.; Williamson, G. Phenolic acids and flavonoids in leaf and floral stem of cultivated and wild L. genotypes. Food Chem. 2011, 126, 417-422. [CrossRef]

37. Cox, D.R.; Box, G.E.P. An analysis of transformations (with discussion). J. R. Stat. Soc. 1964, 26, 211-250.

38. Rencher, A.C. Interpretation of canonical discriminant functions, canonical variates, and principal components. Am. Stat. 1992, 46, 217-225.

39. Zhao, H.; Guo, B.; Wei, Y.; Zhang, B.; Sun, S.; Zhang, L.; Junhui, Y. Determining the geographic origin of wheat using multielement analysis and multivariate statistics. J. Agric. Food Chem. 2011, 59, 4397-4402. [CrossRef] [PubMed]

40. Mauro, R.P.; Occhipinti, A.; Longo, A.M.G.; Mauromicale, G. Effects of shading on chlorophyll content, chlorophyll fluorescence an photosynthesis of subterranean clover. J. Agron. Crop Sci. 2011, 197, 57-66. [CrossRef]

41. Saleh, S.A.; Zaki, M.F.; Tantawy, A.S.; Salama, Y.A.M. Response of artichoke productivity to different proportions of nitrogen and potassium fertilizers. Int. J. Chem. Tech. Res. 2016, 9, 25-33.

42. Ehaliotis, C.; Massas, I.; Pavlou, G. Efficient urea-N and KNO-N uptake by vegetable plants using fertigation. Agron. Sustain. Dev. 2010, 30, 763-768. [CrossRef]

43. Spiertz, H.J. Nitrogen, Sustainable Agriculture and Food Security: A Review. Agron. Sustain. Dev. 2010, 30, 43-55. [CrossRef]

44. Mehraj, U.; Abidi, I.; Ahmad, M.; Gul-Zaffar, Z.A.; Dar Rather, M.A.; Lone, A.A. Stability analysis for physiological traits, grain yield and its attributing parameters in oats (Avena sativa L.) in the Kashmir Valley. Electron. J. Plant Breed 2017, 8, 59-62. [CrossRef]

45. Romani, A.; Pinelli, P.; Cantini, C.; Cimato, A.; Heimler, D. Characterization of Violetto di Toscana, a typical Italian variety of artichoke (Cynara scolymus L.). Food Chem. 2006, 95, 221-225. [CrossRef]

46. Spanu, E.; Deligios, P.A.; Azara, E.; Delogu, G.; Ledda, L. Effect of alternative cropping systems on globe artichoke qualitative traits. J. Sci. Food Agric. 2017, 98, 1079-1087. [CrossRef] [PubMed]

47. Available online: http://eur-lex.europa.eu/legal-content (accessed on 25 January 2017).

48. FAO/WHO. Food Additives and Contaminants. In Joint Codex Alimentarius Commission, FAO/WHO Food Standards Program; ALINORM 01/12A; FAO/WHO: Rome, Italy, 2001.

49. Ackah, M.; Kwablah Anim, A.; Tabuaa Gyamfi, E.; Zakaria, N.; Hanson, J.; Tulasi, D.; Enti-Brown, E.; Saah-Nyarko, S.; Owusu Bentil, N.; Osei, J. Uptake of heavy metals by some edible vegetables irrigated using wastewater: A preliminary study in Accra, Ghana. Environ. Monit. Assess. 2014, 186, 621-634. [CrossRef] [PubMed]

50. Al-Lahham, O.; El Assi, N.M.; Fayyad, M. Translocation of heavy metals to tomato (Solanum lycopersicom L.) fruit irrigated with treated wastewater. Sci. Hortic. 2007, 113, 250-254. [CrossRef]

51. Lombardo, S.; Pandino, G.; Mauromicale, G. The nutraceutical response of two globe artichoke cultivars to contrasting NPK fertilizer regimes. Food Res. Int. 2015, 76, 852-859. [CrossRef]

52. Tomas-Barberan, F.A.; Espin, J.K. Phenolic compounds and related enzymes as determinants of quality in fruits and vegetables. J. Sci. Food Agric. 2001, 81, 853-876. [CrossRef]

53. Ma, D.; Sun, D.; Li, Y.; Wang, C.; Xiea, Y.; Guo, T. Effect of nitrogen fertilization and irrigation on phenolic content, phenolic acid composition, and antioxidant activity of winter wheat grain. J. Sci. Food Agric. 2015, 95, 1039-1046. [CrossRef]

54. Heimler, D.; Romani, A.; Ieri, F. Plant polyphenol content, soil fertilization and agricultural management: A review. Eur. Food Res. Technol. 2017, 243, 1107-1115. [CrossRef]

55. Stefanelli, D.; Goodwin, I.; Jones, R. Minimal nitrogen and water use in horticulture: Effects on quality and content of selected nutrients. Food Res. Int. 2010, 43, 1833-1843. [CrossRef] 
56. Delgado, R.; Martín, P.; del Álamo, M.; González, M.R. Changes in the phenolic composition of grape berries during ripening in relation to vineyard nitrogen and potassium fertilisation rates. J. Sci. Food Agric. 2004, 84, 623-630. [CrossRef]

57. Roberfroid, M.B. A European consensus of scientific concepts of functional foods. Nutrition 2000, 16, 689-691. [CrossRef]

58. Brown, J.E.; Rice-Evans, C.A. Luteolin-rich artichoke extract protects low density lipoprotein from oxidation in vitro. Free Radic. Res. 1998, 29, 247-255. [CrossRef] [PubMed]

59. Speroni, E.; Cervellati, R.; Govoni, P.; Guizzardi, S.; Renzulli, C.; Guerra, M.C. Efficacy of different Cynara scolymus preparations on liver complaints. J. Ethnopharmacol. 2003, 86, 203-211. [CrossRef]

60. Wang, M.; Simon, J.E.; Aviles, I.F.; He, K.; Zheng, Q.Y.; Tadmor, Y. Analysis of antioxidative phenolic compounds in artichoke (Cynara scolymus L.). J. Agric. Food Chem. 2003, 51, 601-608. [CrossRef] [PubMed]

61. Schutz, K.; Carle, R.; Schieber, A. Taraxacum-A review on its phytochemical and pharmacological profile. Taraxacum A Rev. Its Phytochem. Pharmacol. Profile 2006, 107, 313-323. [CrossRef] [PubMed]

(C) 2019 by the authors. Licensee MDPI, Basel, Switzerland. This article is an open access article distributed under the terms and conditions of the Creative Commons Attribution (CC BY) license (http://creativecommons.org/licenses/by/4.0/). 